\title{
Latin Americanism in the Music of Rubén Blades
}

\author{
Juan Pimentel-Otero \\ Department of History and Latin American Studies, University of North Carolina at Charlotte, United States
}

Copyright $(2016$ by authors, all rights reserved. Authors agree that this article remains permanently open access under the terms of the Creative Commons Attribution License 4.0 International License

\begin{abstract}
According to ethnomusicologist Marisol Berríos Miranda, salsa serves as an escape valve for people who live under neocolonial conditions to express their discontents. This paper will discuss the role of nationalism and supranationalism and its manifestation through four of contemporary Panamanian salsa artist, Rubén Blades' songs. His ability to understand social and political conditions throughout the region, allows for him to deploy Latin Americanism-the political philosophy developed by Simón Bolívar-as an anti-imperialist call urging Latinos to counter United States' intervention in Latin America during the Cold War.
\end{abstract}

Keywords Salsa, Latin Americanism, Anti-imperialism, Caribbean

\section{His Life}

Rubén Blades was born into an urban working class family in 1948. His family's diverse cultural and geographical origins are a microcosm of the cultural crossroads that represents the Caribbean. His maternal grandmother was originally from Spain who married a man from New Orleans that participated as one of Roosevelt's Rough Rider's and settled in Cuba, where his mother was born. On the paternal side, his grandfather was an Englishman from St. Lucia-hence the surname Blades-who moved to Panama in the early decades of the twentieth century as part of the Canal effort. His father, Rubén Sr., was born in Santa Marta, Colombia, and then later settled in Panama City where he met and married Anoland Bellido de Luna, Blades' mother.

Growing up, the Blades were a lot like any other urban working class family in Panama City. However, music was always a central part of the Blades' household. Among his childhood musical influences are the big-time Afro Cuban musicians and orchestras, especially Beny Moré. Throughout the 1950s and early 1960s, Blades performed locally in a band inspired by the popularity of American Rock n' Roll. During the late 1960, by the time Blades was in High School and in college, he and his childhood friend,
Roberto Cedeño formed a salsa band called Los Salvajes de Ritmo. It was during this time where he was given his first big-break and recorded his first solo album, From Panama to New York, in 1969.

In 1974, Blades moved to Miami to reunite with his family after Blades Sr. had an alleged problem with the Panamanian police, which he worked for. The dire economic conditions at the time compelled him to go to New York City (NYC), where he was able to land a job as Fania Records' mail clerk. Around that same time, Blades joined Ray Barretto's band as additional singer, gaining notoriety for somewhat abstract and complicated lyrics considered by some unorthodox to the type of salsa that was being produced. During this same time, the Fania All-Stars (the agglomeration of all the bands under the Fania label) spearheaded the "salsa revolution" that took this Afro Caribbean sound around the world.

By 1977, Blades convinced Fania owner Jerry Masucci, to allow him to record with another legendary Fania All-Star member and producer, the Nuyorican (New Yorker of Puerto Rican roots) Willie Colón. In 1978 he and Colón released the salsa classic, Siembra that catapulted Blades as one of salsa's brightest and most sophisticated singers. By the early to mid 1980s, the incredibly successful Blades-Colón duo had come to an impasse as a result of personal differences between the two. Around this time, Blades did a Master's degree at Harvard and recorded another classic album, Buscando América. By the early early 1990s and after Manuel Noriega's arrest by the US, war and Panama's return of democracy, Blades formed a political party and retuned to Panama where he ran for president. After losing those elections, he returned to the US where he continues to star in movies and recording other successful albums as well. In the early 2000s, Blades served as Panama's tourism minister. He has currently retired from active touring and plans to run for president again in the upcoming years.

\subsection{Towards a Theory about His Music}

Some have described Rubén Blades' music as the "thinking man's salsa," while others have condemned his Left-leaning views in a field where political positions are not common (and presumably, should not be). Although still active in music, television, movies and other projects, 
Blades' most politically salient music reflects his understanding of Latin America's relation to the US during the Cold War (1945-1990). This is why the sampled songs included in this article were recorded between 1969 and 1985. As a native Panamanian, he knew from early on that Panama's inferior and neocolonial position to the US was common all throughout the Great Caribbean-the region composed of the Spanish-speaking Antilles, Central and northern South America. As a result, and central to this paper's argument, Blades' forty-five plus year career and a small, yet very significant portion of his music reflects his understanding of US-Latin America relations. This is why only four songs will stand out in this article: "Juan González" (1969); "Plástico" (1979) “Tiburón” (1981); and "Buscando América" (1984).

Born out of the struggles of the Wars of Independence, Latin Americanism was initially unable to cement itself within the newly established states of the region. In spite of this, Latin Americanism kept showing up all throughout the nineteenth and twentieth centuries in the writings and discourses of politicians, thinkers and poets who championed unification to counter imperialism. More importantly, anti-imperialism came to be filtered through Latin Americanism. In other words, from the very beginning, to be a Latin Americanist implied being anti-imperialist.

However, during the Cold War, it very often also implied that being an anti-imperialist probably meant that you were a communist as well. And because Blades' most musically productive years take place precisely during the Cold War, his anti-imperialist views were also shared by Leftist political movements. But most of all, his views resonated with the political discourse of revolutionary Cuba, the Cold War's most ardent political manifestation in Latin America. And this is where a clear interpretation of his music becomes murky. Although clearly an anti-imperialist, nationalist-in fact, Blades' childhood friend, Ricardo Ledezma has described him as "intensely Panamanian"- Latin Americanist, and self-proclaimed Leftist, Blades' music is often boxed into the dual paradigm of Cold War politics by his most ardent critics. In spite of this, he tried to avoid being considered a communist and having his music be considered exclusively as "canción" or "música de protesta." That is, protest music or song.

In his enlightening essay, ethnomusicologist Robin Moore contextualizes protest music or song as a genre born out of the political struggles of twentieth century Latin America. He defines it as a product of "oppositional youth music that supported some government policies and openly criticized others." Additionally, and more importantly, protest music came to be "most closely associated with the Cuban socialist revolution" and generally with the Left in Latin America [1].

In a 1979 interview, Blades was asked about how he sees his music and how it allegedly "bypassed the protest music genre" to which he replied, "But, that's an invention. The term protest music was given to a type of music with a certain political connotation...I never liked protest music because it became too stylish. Partisanship songs don't convince me. I can sign you a song about a social topic with a political tone, but the political tone is the result of the social [conditions] and not it's purpose...I'm not going to sing you a song glorifying Fidel Castro, because I don't think Fidel Castro is a being from another planet, without any defects, why would I sing about Fidel's good attributes and not the bad ones." He also suggested that although his salsa might share the same characteristics as protest music, "but it's not everything" [2]. As recent as 2010, Blades has said, "I've had arguments with both the Left and the Right...I was very careful not to write from a ideological position...this is what happens and then the songs start to sound like pamphlets; pamphletaty songs" [3].

Regardless of his constant efforts not to be cornered ideologically-and perhaps as a result of the reactionary military dictatorships that ruled most of Latin American countries as well as deep-rooted anti-communist sentiments in the US where he has lived from 1974 onwards-Blades always identified himself as a Panamanian and a Latin Americanist. Essentially for him, only the potential unification of the Latin American nations was the solution to counter US hegemony and influence as experienced through Panama's neocolonial relation to the US. Furthermore, it is also important to understand the role of salsa music and how its serves to express social and political discontents for the people of the Caribbean, Latin America as well as Latino communities in the US. Essentially for Blades, salsa "is a international folklore at the urban level that reflects the feelings of Spanish America in search for its unity and identity" [4].

\section{Theoretical Framework and the Origins of Salsa}

What is known as "salsa" today-in Spanish salsa literally means "sauce" or a mixture of different condiments-stems from African and Spanish musical influences that developed in Cuba during the nineteenth and twentieth centuries. In the 1930s, 1940s and 1950s, Afro Cuban music was very popular in NYC's big-band clubs, which catapulted the Latin music fever that spread throughout the US. However, with the success of the Cuban Revolution in 1959, the US turned its back on anything Cuban, which know meant communist.

It was during this time that recently arrived Puerto Rican immigrants, Nuyoricans, Cuban and other Latino musicians started experimenting with old Afro Cuban sounds. Although Latino musicians knew the differences between different rhythms, most Anglo Americans did not. It was then when all Afro Cuban music, infused with Puerto Rican sounds, was labeled as "salsa" basically, to ease its marketing.

Legendary Fania Records bandleader, Johny Pachecho put it best: "Salsa is, and always has been Cuban music. What happened is that we put a New York spin on it and made it more aggressive...we began to travel to Europe, Japan and Africa, places were Spanish wasn't spoken, and to avoid 
confusing people regarding what a guaguancó, guaracha or son montuno was, we put all tropical music under one roof, and we called it salsa" [5]. Simply put, salsa spread from its birthplace in Cuba, developed in Puerto Rico and by Puerto Ricans and other Latinos in NYC as well as throughout the Great Caribbean.

\subsection{Salsa, Social Class and National Identity}

In spite of its "Pan-Latino" scope, salsa was born out of and listened by mostly a specific social class of Latinos. Cuban born, Puerto Rican anthropologist Jorge Duany traces and defines salsa's cultural and musical development. $\mathrm{He}$ fundamentally identifies salsa as a "type of musical manifestation of the urban proletariat." According to Duany, the result of the mass immigration of Puerto Ricans to NYC between 1940 and 1970, led to the creation and development of salsa. Simultaneously, he argues that as a cultural and popular expression, salsa is a "symbol of resistance to the loss of national identity, whether through the migration experience" or as a consequence of the US' "cultural penetration of the Island [Puerto Rico]" [6]. In the same vein, Angel Quintero-Rivera also posits, "contemporary popular music... and particularly salsa, is national in character" [7].

The takeaway from these two authors' points is threefold: 1) salsa was born out of the Puerto Rican and Latino immigrant experience/diaspora as a means to express and retain national and transnational identities, as well as the ills of ethnic Latino communities or "barrios" in NYC; 2) although mostly a product of the "urban proletariat" experience both in the US and Latin America, salsa is mainly, but not exclusively, a working class, and therefore popular genre; and 3) as a genre made up of Afro Caribbean rhythms, salsa is consumed and produced by those countries who possess similar cultural make up. Consequently, salsa is both national (i.e. Puerto Rican, Cuban or Panamanian) and transnational (i.e. Caribbean, Afro Latino) [8].

It is precisely under these same conditions where salsa becomes an outlet to express political ideas. In her study of salsa's role in NYC's barrios during the 1960s and 1970s, ethnomusicologist Marisol Berríos Miranda argues that salsa "represent $[\mathrm{s}]$ a kind of liberation from the cultural and political pressures they [Puerto Ricans and other Latinos] were experiencing at this time" [9]. However, in Blades' case, his music does not start in the US but in his native Panama, providing further proof of salsa's transnational nature.

\section{Origins of Latin Americanism}

As an idea, Latin Americanism can be traced all the back to the South American Wars of Independence (1810-1824). Championed mostly by colonial political and economic elites, Spanish Americanism, as it is referred to by some, essentially argued for the continuation of the Spanish territories to be ruled as a single political unit, much like the
US. This idea was first fomented by the Venezuelan Criollo (American born Spaniard) Francisco de Miranda while exiled in England. Upon his defeat by the Spanish in 1811, another Venezuelan Criollo, Simón Bolívar, took Miranda's stead and became the leader of the Venezuelan and New Granadian (modern day Colombia) independence movement.

While exiled in Haiti in 1816, Bolívar wrote his famous "Jamaica Letter." In it, he fomented the idea that Spanish America ought to be organized under a "single government to permit the newly formed states to unite in confederation" [10]. After years of grueling battle through some of the earth's most extreme weather zones, in 1821, Bolívar defeated the Spanish armies of the former Viceroyalty of New Granada and established the Republic of Colombia. A state composed of the former province of Venezuela, New Granada and Quito (modern day Ecuador). Effectively, Colombia was a direct product of his continental plans.

In spite of his military victory in northern South America, Bolívar acknowledged that as long as the Spanish did not continue to occupy American territory, Colombia nor his grandiose political project would survive. As a result, he and his armies pushed southwards towards Peru, the last Spanish stronghold in South America. Simultaneously, the Argentine General José de San Martín, pushed north from the provinces of Río de la Plata (modern day Argentina, Uruguay and Paraguay) and with the Chileans, occupied Lima without fully defeating the Spanish.

It was then when in a concerted effort that Colombian, Chilean and Argentinean forces defeated the Spanish at the battle of Ayacucho in 1824. All throughout this time moreover, Bolívar-being the skilled statesman and diplomat that he was-struck treaties with Peru, Río de la Plata, the United Provinces of Central America and Mexico that would serve as a prelude to the Spanish American Confederation that he envisioned years earlier.

In 1826, representatives from most these countries convened in Panama-where Bolívar imagined the capital of this great continental union would be-to further develop the idea of League and Confederation [11]. However, the diplomatic rapprochements among the former Spanish provinces fell through and no confederation treaty was ever agreed upon. Additionally, a military insurrection in his native Venezuela threatened to break the fragile Republic of Colombia apart. That same year, Bolívar left Peru for Bogotá, then Caracas.

After reigning in the insurrection led by his former general and president of the department of Venezuela, José Antonio Páez, Bolívar returned to Bogotá only to find himself among many enemies. Colombia's vice president, general Francisco de Paula Santander, conspired against him and in 1828, even tried to have the "Liberator," as Bolívar came to be known, killed. Once he escaped and returned to his active role as president, Bolívar convened a constitutional assembly that would work out the major political differences that were never fully addressed years earlier.

In spite of his efforts to save the Republic, Bolívar failed 
and was later exiled. While trying to reach the Caribbean coast, Bolívar died of tuberculosis and his dream of a united Spanish America died with him. By 1830, both Venezuela and Ecuador seceded; all that remained of the original Republic of Colombia was the Republic of New Granada. And although Spanish Americanism failed as a political project on the continent, the weight and influence of its core ideas-the union of kin peoples and anti-imperialism-survived.

Because Cuba and Puerto Rico remained as Spain's American colonies, Spanish Americanism saw itself revived by Cuban and Puerto Rican independence advocates. In fact, Puerto Rican patriot, Ramón Emeterio Betances, argued in favor of the Antillean Confederation, the union of the Spanish-speaking Antilles to fight Spanish imperialism. Later in the nineteenth century, the Cuban intellectual José Martí took this same stance. As a result of Martí's Latin American travels, he developed the idea of "Nuestra America" or, "Our America," meaning the America of Spanish and Latin origins as opposed the "America" of the North [12]. More importantly, it is during this time that Latin Americanism becomes synonymous with anti-imperialism, especially in the Caribbean Basin.

But Spanish, or Latin Americanism (at this time the "Latin" factor was emphasized over the "Spanish" thus including Portuguese-speaking Brazil as well) instead of expressing itself through politics as it was during the early nineteenth century, found ample support among intellectuals throughout the region as a result of the US intervention in Cuba and Puerto Rico during the Spanish American War of 1898.

The expansion of the US into Latin America encouraged Uruguayan intellectual José Enrique Rodó to "redeem" Latin America's honor in the face of "North American imperial arrogance, gunboat diplomacy, and big-stick policies" [13]. It was through the epic poem Ariel then, where Rodó urged Latin America's youth to "rise up in blood in muscle" to defend "Our America." Nicaragua's Ruben Darío follows suit by claiming, "Our Fatherland is one; it begins at the Río Bravo [Grande] and ends in the muddy hills of the Patagonia" [14]

The point of this summary is to show how Latin Americanism began in politics and failed only to reemerge out of the dustbin of Latin American political thought as a result of the US imperialism in the Caribbean and Central America during the first half of the twentieth century. The point is to also demonstrate that political ideas such as these are not necessarily manifested exclusively through conventional political channels. Martí was a man of letters; Rodó a college professor; Darío, a poet. However, as politically conscious individuals, all these men understood that at the core of Latin America's weakness was its fragmentation into small weak states.

At the beginning of the twentieth century, most countries in the region developed isolated from one another, many times, looking at their neighbors with suspicion. However, as the twentieth century progressed, so too did Washington's involvement, the most outstanding examples being the military expedition into Mexico during its Revolution and the Marines' campaign in Nicaragua. And although Latin Americanism was weak politically, it was still deployed by many thinkers, writers and poets throughout the region denouncing US imperialism. Soon too would it find ample space through Blades' music?

\section{US Cold War Policies in Latin America}

By the time Blades was born, the US had been occupying the Canal Zone for nearly fifty years. As a military, economic and cultural enclave splitting Panama in half, the Canal Zone was a powerful example of the US' power and influence throughout Latin America. After the end of the Second World War and the start of the Cold War, the US became increasingly suspicious of any communist activity in its "backyard." What happened in Guatemala in the 1950s perfectly exemplifies the US' Cold War policies towards reformed oriented governments and set the example of how to remove them from power elsewhere.

Starting with Juan Jose Arévalo's presidency in 1945, Guatemala witnessed two back-to-back reformist administrations whose main purpose was to change the vast inequalities. At the end of Arévalo's term, his successor, Jacobo Arbenz Guzmán took reforms even further. Under his direction, large plots of land were distributed to poor peasants. Unfortunately for Arbenz, the confiscation of land belonging to the United Fruit Company immediately raised red flags in Washington. Consequently, in 1954, the CIA orchestrated a coup that ousted democratically elected Arbenz from power, installing a government friendlier to US (something which during the 1970s and 1980s will be commonplace) economic and political interests [15]. Two years later, Arévalo wrote a short book called The Shark and the Sardines, essentially portraying the US as a predatory shark while characterizing Latin American countries as sardines [16].

\subsection{Panama's "Loss of Innocence"}

In Panama, young Blades-who started to perform in salsa bands with family and friends around this same time-witnessed the events happening throughout the region. But it was what happened in his country that influenced his political worldview.

The US' virtual ownership of the Canal Zone only highlighted Panama's neocolonial status. As a result, the US government did not allow the Panamanian flag to fly along the "Stars and Stripes" anywhere within the Zone. On 9 January, 1964, a group of approximately two-hundred Panamanian students marched towards Balboa High; a US ran school for US service member families' and Zone employees. With the intention of hoisting their flag, the Panamanian students met resistance from their US peers. 
Tension turned to violence and in the end, over twenty Panamanian citizens were killed by Zone military police. Referred by Panamanians as Martyr's Day, this tragedy resulted in Panama temporarily breaking all diplomatic relations with the US. Years later, Blades claimed that the US "killed any illusion of equality," and that as a result he "began to read a lot more history [and] politics" [17].

Consequently, it was around this time that Blades began to notice the political conditions of Panama and Latin America. “...I begin to understand the local socio-political argument, the international economic and realities, and who I am as a Panamanian, then I start establishing an inclusive observation of the rest of the Spanish-speaking counties and visualize the same problems, the same questions, the same aspirations and thus, we may share the same answers" [18]. And it was precisely through Latin Americanism that Blades hopes that there lies a solution to Latin America's problems.

Musically, prior to Martyr's Day, Blades was fond of Rock and Roll and even sang in English. This changed, too. However, at this point, Blades, now approaching his twenties, was still musically and politically premature. It would not be until 1969 where his skills as a "political observer" will be seen.

That year, several NYC based salsa producers reached out to Blades after they had seen him perform while touring Panama. During his law studies at the University of Panama, they offered him a trip to NYC and eventually recorded his first "major" album, From Panama to New York. If anything, the album's success was marginal. However, the song "Juan González" became the first song that mirrored what was happening throughout Latin America.

\section{5. "Juan González"}

A fictitious tale about a rebel leader and his band of revolutionary guerrillas somewhere in Latin America, "Juan González" and his followers are eventually ambushed and killed by government forces. After the firefight, the song tells how a jeep makes its way down to town declaring their victory over the rebels. Blades' narrative in "Juan González" and its similarities with Argentine revolutionary Ernesto "Che" Guevara are not coincidental. "The song begins marking my path into a musical narrative," says Blades. He adds, "[I] ... was also influenced by Che Guevara's death that had occurred two years earlier" [19].

As a result of the dangerous political climate in Panama and across Latin America, Blades' music is characterized by its ambiguity and contradictions. For instance, at the beginning of "Juan González" he says, "any similarity to people either dead or alive is purely coincidental," thereby minimizing government backlash. After all, it was during this time that General Omar Torrijos took over Panama. "You're not going to do an album about a guerrilla fighter thinking you're going to get airtime," says Blades. "What's going to happen is that they're [government] is going to put you on the black list!" He adds, "In Panama, something very interesting happened. The record was very successful in the Enlisted Club [a club for enlisted soldiers]. And I know this because the guy that used to take out the coins from the jukebox told me. I asked him, "Which one? Juan González? That can't be. How comes?" And he told me, "Because the song says that the guy got killed, that is, the army kills him. They won"[20].

Blades' personal testimony is the key to understanding the context in which it took place. Although this song was clearly paying homage to Che Guevara and the many guerrillas that took up arms throughout Latin America, it shows that Blades was careful enough to fictionalize actual historical events and people. To outright romanticize Che's story two years after his demise would have been a careless and dangerous mistake. Additionally, it shows his ability to appropriate the Left's causes without labeling himself as a communist.

\section{6. "Plástico"}

The Blades-Colón duo proved to be a successful model that Fania Records continued to pursue. In 1978, they released perhaps one of the most popular salsa albums ever released, Siembra, which means to sow or to plant. Among this album's hit singles were "Buscando guayaba" and "Pedro Navaja," Blades' redo on an old jazz classic titled "Mack the Knife." However, the track "Plástico" or plastic, exemplifies Blades' Latin Americanism like no other before it.

A multi-layered song, "Plástico" essentially argues against the superficiality of materialism embodied in a couple that wishes to maintain appearances as belonging to a higher social class. Moreover, Blades' critique also points out Latin American racism exemplified in the couple's reluctance to have their five-year-old child play with darker-skinned kids. "Plástico" also criticizes Latin American cultural and social "wannabeism" in the form "imported models which aren't the solution." Essentially, a jab against how Latin American nations and Latinos themselves have strived to imitate the West [21].

"Plástico" closes by calling upon all Latinos to fight against "selling out" and submissive ignorance, both at the individual and social level. Blades' fight against ignorance, submissiveness and falsehoods-hence, the plastic element-encourages him to rely upon the faces of hardworking Latin Americans as the true proof of what he understands Latin America to be. His calling for a "new path" moreover, should hinge upon the notion of a "raza unida" or unification of Latin Americans as "Bolívar dreamt." Clearly then, this "new path" is the reaffirmation of Latin American identity that would be reinforced through an implicit political unification as suggested by Bolívar's brand of Latin Americanism. "Plástico" ends by Blades roll-calling each Latin American country, starting with his native Panama. As a result and as Jairo Moreno argues, this action "Comes across as a recitation of Bolívar's own verbal map of 
the American confederation," thereby allowing Blades to assume a position of authority and leadership" [22].

Besides the content itself, how was Siembra and its message received? Blades himself states, "Siembra sold 45,000 copies in Caracas because although the argument was described and recorded in New York, it wasn't solely a New York argument. It was an argument of the person. And why did it move so well? In fact, people who didn't dance salsa bought it. In other words, it was the moment where things fell apart...it was an urban argument...salsa established the common ground for the urban argument as for other existing expressions" [23].

On that same note, the percussionist José Mangual Jr., who worked on Siembra as well, said that, "The people who were buying Siembra were not strictly dancers confined to the ghetto; they were coming out of the universities and they were thinkers; ambitious young people who heard the message and made a decision to do something positive with their lives and not go the way of the Pedro Navaja stereotypical character" [24].

These two testimonies reflect how Blades' music has enough "street" for the typical salsa listener/dancer of the Latino ghettos in NYC to consume, as well as across Latin America. Similarly, as opposed to the salsa recorded before and during this same time, Siembra's message of a "pan-Latino consciousness" or, Latin Americanism, resonated to people who were not confined to the barrios in NYC or any other large Latin American city. Blades' salsa surpassed the means which it projected itself and penetrated the class barriers that salsa has historically been concentrated in.

\section{7. "Tiburón"}

A few years later, in 1981, Blades and Colón strike again, this time, through the controversial single "Tiburón" or "Shark." Playing on Arévalo's work, the song begins by transporting the listener to a remote beach in the Caribbean. The song perfectly characterizes the sounds one would expect to hear while at the beach; children playing, seagulls squawking and waves crashing on shore.

In this track, Blades portrays a scheming and predatory Shark moving about the Caribbean Basin looking for victims to devour. He simultaneously depicts this same Shark as a mermaid, highlighting its mind-altering abilities. In the song, Blades is aware of the Shark's intentions, as a result, he urges that if "you see it coming, stick it to the Shark" and "let's hit him hard, without fooling around" [25].

Additionally, by speaking in the second person, he is actively inviting Latin Americans unite against the Shark, which in this case is characterized by the US. By saying that "our strength and salvation lies in unity," he echoes Bolívar's cry during Colombia's last days: "unity, unity, unity or anarchy shall devour you all." Consequently, if Latin America's salvation lies in its unity, the region's instability during the 1980s, at least for Blades, must have been some sort of Hell. It must not be overlooked that during this time, Nicaragua, El Salvador and other South American countries were experiencing civil wars, contra-revolutionary coups and repressive regimes. "Tiburón is an anti-imperialist song," says Blades. "When we talk about it the first thing is 'Yankee' imperialism; well that's one form of it...I was out of the radio for fifteen years in this country because of 'Tiburon'” [26].

Years later, in an interview with Argentinian public television, it was brought up that most of Blades' career had taken place in the US. That is, he made his political critiques from the safety of a New York studio, that is, "inside the Shark," alluding to Jose Marti's anti-imperialist view of the US while living in it. To this, Blades responded, "Well, that's interesting, because there's an anecdote about that point that has to do with José Martí. When Martí leaves Cuba and comes to the US and starts talking about Cuba, a guy shouted 'instead of saying it here why don't you say it in Cuba?!' Martí replied, 'for saying it over there is why I'm here."” Blades continues, "I've never had the problem with the people of the US, nor have I had the problem with Rock n' Roll, or Marilyn Monroe or the New York Yankees. My problem has been with the policies applied by the US government...second of all, it's harder to say it from within that outside. If I were singing 'Tiburón' in Cuba they'd give me a house. I sang 'Tiburón' here and they put me on a blacklist from fifteen years" [27].

These statements clearly show that Blades is aware that his positions are contradictory. Furthermore, it shows what this paper has been arguing all along. Although clearly an anti-imperialist and Latin Americanist, his views were more or less self-regulated. $\mathrm{He}$ was and continues to be a established in the US, thus, he is aware that his anti-imperialists views do not get muddled into radical anti-US feelings that are commonplace among the Latin American Left.

\section{Buscando América}

By 1984, Blades' had finished a Master's at Harvard as well as several other musical and movie projects, and was a well-known "crossover" Latino artist. In spite of this, it was that same year that he released arguably his best work, the album titled Buscando América, meaning "Searching for America." This "America" however, was not the US. The America Blades sought was Martí's America. That is, Latin America, as suggested by writing the word with the accent over the "e."

In any case, this album beautifully covers what was happening in the region during this time. In the song "Desapariciones" or "Disappearances," Blades reflects the political disappearances that took place during Argentina's dictatorial junta in the 1970s and 1980s. In the song "El padre Antonio y su monaguillo Andrés," or "Father Anthony and his Altar-boy Andrés," he pays homage to the brutal slaying of Salvadorian archbishop Arnulfo Romero, who 
was killed while saying mass by the reactionary government of El Salvador in 1980.

However, this album's flagship track is the song that bears the same name, "Buscando América." Essentially a song covered by "melancholy and mourning," this song represents how for Blades, Latin America was "lost among the darkness." But overall, and as Moreno again suggests, "Buscando América" expresses Blades' grief and "his refusal to admit to the vanishing dream of a united Latin America" [28]. For Blades, the region's reduction to weak states and defenseless fiefdoms as in the case of the Caribbean and Central American countries, on top of the region's general hopelessness amid Cold War politics is perhaps to Blades Latin America's lowest state of historical existence.

\section{Conclusions}

This paper seeks to expose how Rubén Blades used his music to express the ideas embodied in the political philosophy known as Latin Americanism. Although mostly advanced by poets, thinkers and intellectuals in the nineteenth and twentieth centuries, and as a result of US imperialism in the region, the idea of a united Latin America again comes up through the music of a Panamanian salsa artist living in the US during the Cold War. Consequently, Blades' music is a cultural response albeit based on political ideas proposed as an across-the-board alternative to Latin America's problems.

The fact that during this same time Puerto Ricans constituted NYC's numerically predominant Latino national group whose relation to the US was almost exactly the same as Panama's only fueled Blades' notion of Latin Americanism as anti-imperialism as well. This is most evident in "Tiburón" and through the strong acceptance and fondness that Puerto Ricans have towards Blades. Furthermore, the US' direct and indirect involvement in propping up anti-communist regimes in Chile and El Salvador; its role in supporting the Nicaraguan Contras; the exposure of the massive human rights violations in Argentina as a result of the dictatorship encouraged him to idealize Latin America as a lost place which he musically explored in "Buscando América." This paper however, has several key takeaways. First, Blades' music is not "protest music", meaning that he has explored other topics throughout the years. The fact that only four songs were sampled in this paper which simply underscores the complexities of Cold War dynamics; mainly, the fact that he was living in the US when he composed them. Second, this reality translates into his political positions. That is, although to the Left of the spectrum of Latin American politics, he is not an outright communist. He is part of a small, yet influential segment of Latin Americans that promote Leftist ideals of social justice, democracy and anti-imperialism without being "anti-American." And finally (and again), these four songs make that point. Blades is first and foremost a nationalist and a Latin Americanist. He believes in the unifying qualities of this ideology and its redemptive nature for Latin America before the Cold War completely altered the political-ideological spectrum of what it meant to be a Latin Americanist yet not necessarily opposing the US as an existential entity incompatible with Latin America.

Finally, Blades did not conform solely to music. In fact, after the US invasion of Panama in the late 1980s, he ran for president and lost. Mainly because-and self-admittedly-he did not pay as much attention to the campaign as it ultimately required. In the mid-2000s, under the presidency of Martín Torrijos, Blades acted as Minister of Tourism. Bottom-line, he is far from being just a singer. Ironically enough, nowhere is his official policies does he advocate for a political Latin Americanism as embodied by Venezuela and the progressive governments of Latin America. In fact, he is perhaps one of the most vocal critics of the "stupid Left" that has dominated continental politics for the last fifteen years, and which are currently undergoing significant changes, especially in with the Right reassuming the executive branch in Argentina and the legislature in Venezuela. Finally, last year marked the end of his career as a touring artist in order to pursue a second shot at Panama's presidency. Should Blades win, will we finally see his Latin Americanism formalize through policies?

\section{REFERENCES}

[1] Moore, R. From the canción de protesta to the nueva trova, 1965-85, Qualitative Studies in Education, 2001, Vol. 14, No. $2,177-200$

[2] Blades, R. Interview by Herrera, T, Si no existiera la muerte, Ahora, No. 4, agosto-septiembre, 1979.

[3] Blades, R. Interview. Online available from YouTube: https://www.youtube.com/watch?v=31pGCLF_y44

[4] Blades, R. Interview by Azúa, M.E. Rubén Blades: ¡se retira pronto; Artistas, No. 22.

[5] Pacheco, J. Interview. Online available from YouTube: https://www.youtube.com/watch?v=NE9VQXgMebo

[6] Duany, J. Popular Music in Puerto Rico: Towards anthropology of salsa. Latin American Music Review/Revista de música latinoamericana, Vol. 5, No. 2 (Autumn-Winter 1984) 186-216.

[7] Quintero-Rivera, A.G. Music, social classes and the national question of Puerto Rico. Latin American Program, Working Papers, The Wilson Center, Smithsonian, 1989, 2-45.

[8] Rondón, C.M. The Book of Salsa: A Chronicle of Urban Music from the Caribbean to New York City. UNC Press, Chapel Hill, 2008.

[9] Berrios-Miranda, M. Salsa as an expressive liberation, Centro Journal, Fall, Vol. XVI, No. 002, City University of New York, Centro de Estudios Puertorriqueños, 158-173.

[10] Bolívar, S. Reply of a South American to a gentleman of this 
island, September 6, 1816. Lecuna, V. and Bierck, H. eds. Selected Writings of Bolívar, Vol. 1, 1810-1822. Colonial Press, New York, 1951.

[11] Bolívar, S. To the foreign ministers of the Spanish-American republics, December 7, 1824. Lecuna and Bierck, Selected Writings.

[12] Martí, J. Our America: Writings on Latin America and the Struggle for Cuban Independence. Monthly Review Press, New York, 1977.

[13] Rodó, J.E. Ariel. University of Texas Press, Austin, 1988.

[14] Darío, R. Tantos vigores dispersos: ideas sociales y políticas. Ediciones Cultural, Managua, 1984.

[15] Chasteen, J.C. Born in Blood and Fire: A Concise History of Latin America. W.W. Norton \& Company, New York, 2006.

[16] Arévalo, J.J. La fabula del tiburón y las sardinas. Monte Ávila Editores, Caracas, 1956.

[17] Blades, R. Interview by Hamill, P. Hey, It's Ruben Blades: A Latin Star Makes his Move. New York Magazine, Vol. 18, No. 32, August 19, 1985, 42-49.

[18] Blades, R. Interview by Borges, E. Vínculos: Apuntes con Rubén Blades. Leer:e, Pamplona, 2013.

[19] Blades, R. Interview, El Show de Ruben Blades, No. 8, 4/5. Online available from YouTube: https://www.youtube.com/
watch?v=ZAKRnV5cA-A

[20] Blades, R. Interview by Bahiano, Mp3: Gira Latina: música para el tercer milenio. Online available from YouTube: https://www.youtube.com/watch?v=SO2rkqj85C4

[21] Blades, R. Colón, W. "Plástico,” Siembra. Fania, 1978.

[22] Moreno, J. Tropical discourses: community, history, and sentiments in Ruben Blades Latin Music. Journal of Popular Music Studies, 2002, 133-163.

[23] Blades, R. Interview. Online available from YouTube: https://www.youtube.com/watch?v=HVifQZ9BjR0

[24] Alvarez-Peraza, C. Echoes of an era: Siembra, Latin Beat Maganize, November 2008, 33.

[25] Blades, R. Colón, W. Tiburón, Canciones del solar de los aburridos. Fania, 1981.

[26] Blades, R. Interview, In His Own Words, part 6. Online available from YouTube: https://www.youtube.com/watch?v $=\mathrm{OjvNhNq} 2 \mathrm{BdM}$

[27] Blades,R. Interview, Músicos de Latinoamérica. Online available from YouTube: https://www.youtube.com/watch?v $=\mathrm{BD} 0$ VvfcF2Oo\&list=RDBD0VvfcF2Oo\#t=17

[28] Moreno, J. Tropical discourses: community, history, and sentiments in Ruben Blades Latin Music. Journal of Popular Music Studies, 2002, 133-163. 